\title{
The magnitude of unclaimed end of life vehicles and environmental implications in police stations' yards: a case study of Nairobi, Kenya
}

\author{
Joseph Kinyanjui Muiruri \\ Kenya Industrial Research and Development Institute, Nairobi, Kenya
}

Email address:

jsphkinyanjui@gmail.com

\section{To cite this article:}

Joseph Kinyanjui Muiruri. The Magnitude of Unclaimed End of Life Vehicles and Environmental Implications in Police Stations' Yards: A Case Study of Nairobi, Kenya. American Journal of Environmental Protection. Vol. 3, No. 2, 2014, pp. 51-58.

doi: 10.11648/j.ajep.20140302.12

\begin{abstract}
One of the Kenyan government visions is to transform Nairobi City into a metropolis by 2030 and this will not only come with improved road infrastructure but also an increase in vehicle ownership rate. Vehicles are essential to society and are continually increasing in use. In Kenya, road transport accounts for $93 \%$ of passenger and freight mobility with over 1.3 million registered vehicles. Over 780,000 vehicles (approximately 60\%) operate in Nairobi. The vehicles often come to the end of their useful lives and stockpiles of unclaimed vehicles are a common sight in police stations' yards in Kenya. Although, unclaimed end of life vehicles have the potential to pollute the environment they are also recyclable resources. To understand this waste management problem which is one of the challenges to development in Kenya and Africa, this study investigated the magnitude (nature and extent) and environmental impacts of unclaimed vehicles in police stations' yards in Kenya. Standardized questionnaires and focused group interviews were used to collect data on number of unclaimed vehicles, vehicle type, category and potential environmental impacts. The preliminary results of the research show that passenger cars and matatus were predominant types at $42 \%$ and $24 \%$, respectively. $86 \%$ were non-operational vehicles while $14 \%$ were operational vehicles impounded due to traffic rules infringement. The potential environmental impacts included contamination of land and water supplies by leaking fluids e.g. engine oil, possible injuries due to rusting broken vehicle parts, potential health hazard risks to children living within the police stations, breeding places for rodents, mosquitoes and other pathogens. The vehicles also cause obstruction (visual pollution). The conclusion can be drawn that unclaimed vehicles' problem requires immediate decisions and actions in order to curb it or else it will get worse as motorization and population increases rapidly. Following statistical analysis of the results, some recommendations will also be presented.
\end{abstract}

Keywords: Freight Mobility, Impact, Unclaimed Vehicles, Waste Management

\section{Introduction}

Automobile manufacturing has increased in the last 20 years reaching 58 million units in 2000 in the European Union. The increasing vehicle production and use data indicate the importance of the automobile industry in society $[1,2]$. In 2010, the ministry of transport in Kenya reported that there were an estimated 1.3 million registered motor vehicles in the country; 60,000 being registered annually. Over 780,000 vehicles representing $60 \%$ operate in Nairobi. The matatu welfare association, representing a section of public service vehicle operators, estimated there were 12,000 fourteen-seater matatus representing $80 \%$ of all the public service vehicles. The vehicle ownership rate in Nairobi was approximately
$23.3 \%$ in 2004 and expected to reach $49.2 \%$ by 2025 [3].

With the expected increase in volume of vehicles on our roads, the fundamental question is, where will these vehicles go after they have reached the end of their useful lives and what are the associated environmental implications?

An end life vehicle (ELV) is a specified vehicle, which is discarded or is to be discarded by its registered owner as waste. These vehicles are non-operational; no longer able to be used since they are wrecked or mechanically irreparable and have come to the end of their useful lives due to either age or heavy damage following an accident. End of life vehicles may be broken down into two categories; natural and pre-mature end of life vehicles. A natural end of life vehicle is one that has come to the end of the road due to natural factors. A pre-mature end of life vehicle on the other hand is one that is 
no longer in use due to accidents [4].

Research on end of life vehicles has been prompted by the realization that cheaper prices for new and used cars and the psyche of a 'disposable society' has made it easier to dispose of and replace a car that had reached the end of its useful life [5]. Earlier investigation on end of life vehicles in New Zealand showed that the exact number of vehicles that have to be disposed of annually is not known but the vehicles removed from registration increased from $2.2 \%$ in 1988 to $10.6 \%$ in 1998. In another study by Cassells [6], two specific questions were addressed. First, the extent of 'abandoned' vehicle problem and secondly, the environmental concerns regarding abandoned vehicles. The sample consisted of 73 city and district councils. Statistics in 66 districts and cities show that over 14,600 vehicles were dumped in 1999. The study further noted that between May 1999 and September 2000, police had impounded 17,247 vehicles due to infringement of the law by drivers.

There is relatively sparse research on end of life vehicles due to some reasons. First, end of life vehicle generation rates are usually estimated on an annual basis based on vehicle retirement data. This is attributed to automobile owners in developed countries permanently retiring their vehicles for a variety of reasons such as: loss of structural $/$ mechanical integrity from corrosion or an accident, poor reliability of parts and components and degraded performance [7]. Secondly, in developing countries like Kenya, vehicle retirement data is inconsistent as a result of automobile owners not permanently retiring their vehicles. Automobile owners invest additional resources in the form of parts and components to potentially extend the life of the vehicle and therefore old vehicles that ought to have been permanently retired are still on Kenyan roads. Over the years, vehicles involved in accidents and those impounded by police over traffic rules infringement are taken to the police stations for further investigations, legal prosecutions or insurance claims. Most police stations' yards have stockpiled end of life vehicles that remain abandoned and unclaimed by their owners. Thirdly, several governments have come up with legislations and policy measures towards management of end of life vehicles. A good example is the European Union countries that came up with Directive 2000/53/EC, aimed at reducing the amount of waste created by end of life vehicles [4)]. The Japanese government introduced the law recycling of end of life vehicle in 2002 [8]. According to Chen [9], China passed a law in 2001 regulating the disposal and recycling of ELVs. A pilot industrial demonstration of ELV dismantling and disposal was established in Shanghai in 2005.

This study is motivated by the complexity of permanently retiring vehicles in developing countries like Kenya and the sight of old end of life vehicles in many police stations' yards. The research setting for this study was the greater Nairobi area comprising of police stations in nine police divisions.

The study helps to understand and articulate linkages between aspects of this waste management problem by answering the following questions:

What is the current state of unclaimed end of life vehicles problem in police stations' yards in Nairobi in terms of vehicle type, category and quantities?

What are the associated undesirable environmental impacts? What are the mitigating measures?

The nature and extent, environmental impacts, as well as institutional responses and management to unclaimed end of life vehicles in police stations in Kenya will be studied. The study is designed to examine the perspectives of stakeholder groups (Traffic police department, Matatu owners association, Kenya institute of public policy research and analysis, Kenya vision 2030 secretariat, Ministry of environment and mineral resources, Ministry of transport, Automobile repairers associations, Insurance industry) on unclaimed end of life vehicles in the yards.

\section{Study Area}

The public survey was carried out in Greater Nairobi area (Figure 1) between January 2013 and May 2013. The focus of this study is Nairobi area with a total landmass of $684 \mathrm{~km}^{2}$ and a population of 3.1 million people (2009 census). The geographical coordinates of Nairobi city are $1^{\circ} 17^{\prime} \mathrm{S}$ and $36^{\circ} 49^{\prime} \mathrm{E}$. As such, Nairobi lies near the equator in the Kenya highlands at an elevation of 1795 meters $(5889 \mathrm{ft})$ This particular location was considered most suitable since in October 2004, Nairobi was expanded to a greater Nairobi taking part of Rift valley, eastern and central provinces with nine police divisions and over 780,000 vehicles representing $60 \%$ operate of the vehicles in Nairobi.

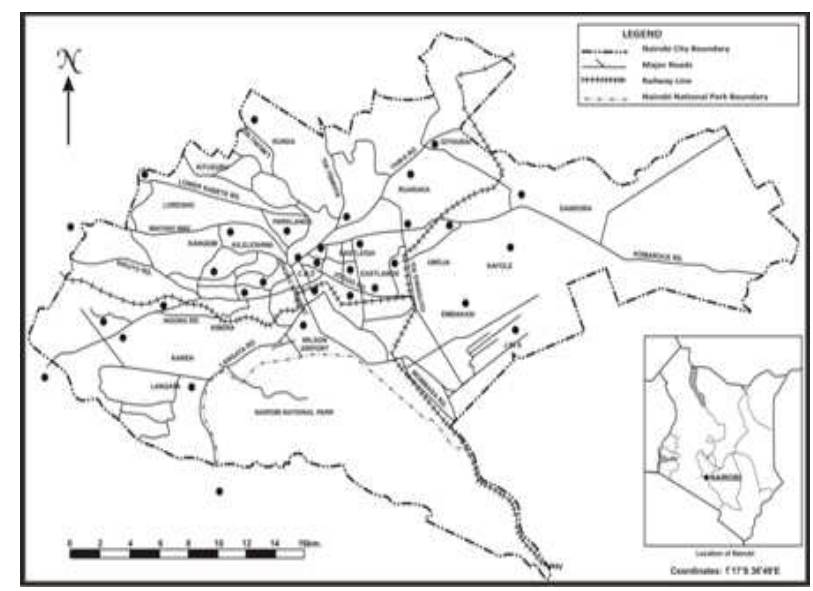

Figure 1. Location of Nairobi within Kenya (inset) and map of study area with dots representing police stations. (Source: Modified from Survey of Nairobi and its environs, 1978).

\section{Materials and Methods}

The aim of this study was to investigate the magnitude (nature and extent) and environmental impacts of end of life vehicles in police stations' yards and at giving recommendations based on the findings. The research design was descriptive survey as well as exploratory method. Standardized questionnaires were used on 118 respondents from 24 police stations selected through stratified random 
sampling and simple random sampling techniques, respectively. In order to get reliable and accurate data, 21 individuals representing seven relevant stakeholders were selected through purposive, snowballing technique. An interview schedule was therefore used to obtain stakeholders' views on end of life vehicles.

\subsection{Participants}

The Participants included officers commanding police divisions; OCPDs (7\%), officers commanding stations; OCS's (17\%) and police officers $(76 \%)$ in traffic police department in Nairobi area. In the qualitative part aiming to explore environmental impacts, the study population comprised of stakeholders involved in the field of urban transport and policy/law enforcement. The stakeholder groups were:

- Public sector (Ministry of transport (MOT) $n=2$, Ministry of environment and mineral resources (MEMR) $\mathrm{n}=2$, Kenya institute of public policy research analysis (KIPPRA) n=2, Kenya vision 2030 secretariat $n=2$.

- Private sector (Matatu owners association (MOA) $n=7$, Insurance industry (IRA) $\mathrm{n}=3$, Automobile repairers association (KARA) $n=3$.

\subsection{Demographic Characteristics of the Participants}

This subsection summarizes background characteristics of participants. Fig. 2 shows that $18 \%$ among the 118 respondents were female, while the male dominated with $82 \%$.

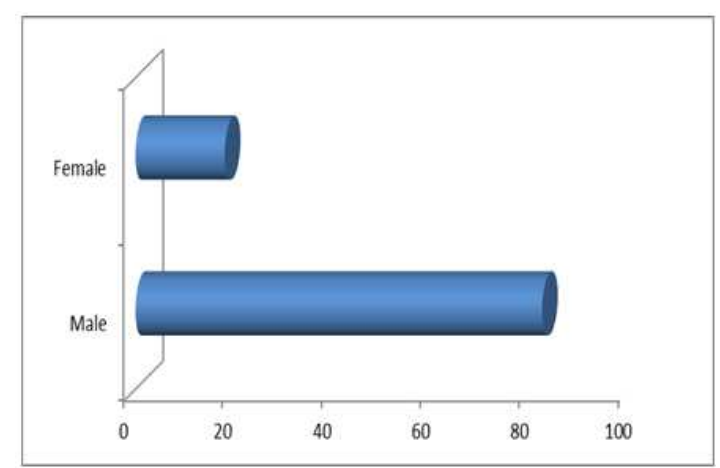

Figure 2. Gender profile of the respondents. Source: Field work, 2013.

\subsection{Procedure}

Relevant authorities were contacted for permission to collect data. The purpose of the research as well as the techniques and procedures for questionnaire survey were explained to the participants. Subsequently, one hundred and fifty (150) questionnaires were distributed through stratified random sampling technique. One hundred and eighteen (118) questionnaires were returned; a return rate of $78.7 \%$. The questionnaire considered the following aspects:

i. Knowledge and reaction towards unclaimed end of life vehicles.

ii. How many vehicles by type and category were lying as waste in the police station yards?

iii. How many of these vehicles belonged to the police station.

iv. Disposal measures in place.

Some of the questions were close ended questions and dichotomous (yes, no) questions. The option 'do not know' was given with the appropriate questions. These questions were particularly useful as they allow respondents to miss out irrelevant questions. In section two and three, the respondents were asked open ended questions about the potential environmental impacts of the stockpiles of unclaimed end of life vehicles and probable solution to the end of life vehicles waste management problem. The focused group interview was guided by an interview schedule to obtain stakeholders' views on end of life vehicles.

\subsection{Data Analysis}

The data was analyzed using a software package called Statistical Package for Social Sciences (SPSS). A significance level of $95 \%$ (or 0.05 ) was set. . Data collected were analyzed using Descriptive statistics, Chi-square, Kruskal Wallis H-test, Spearman's rank correlation and cross case analysis.

\section{Results}

\subsection{Nature and Extent of Unclaimed End of Life Vehicles}

This section aimed at establishing the respondent's views on the nature and extent of unclaimed end of life vehicles as presented in Fig. 3 and 100\% of the respondents stated that the police station had unclaimed, non-operational vehicles in their yards. In total, there were two hundred and forty (n $=240$ ) unclaimed, non-operational vehicles in their yards. Out of these, 26 belonged to the police stations.

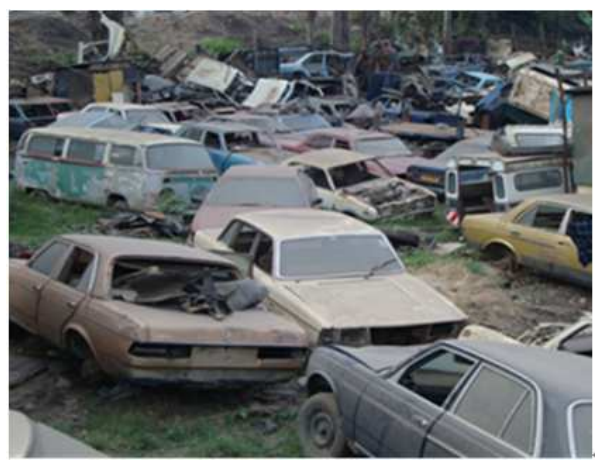

Figure 3. A typical stockpile of unclaimed end of life vehicles in police station yard. Source: Field work, 2013.

\subsection{Types of Unclaimed, Non-Operational Vehicles in the Yards}

This section aimed at establishing the types of unclaimed end of life vehicles in yards. Fig. 4 shows that majority of the vehicles in the police yards were cars comprising $42 \%$ while $24 \%$ were matatus. Sixteen (16\%) percent of the vehicles were buses while 14 percent were pickups and Lorries. The remaining 4\% were tractors and heavy commercial trucks. 


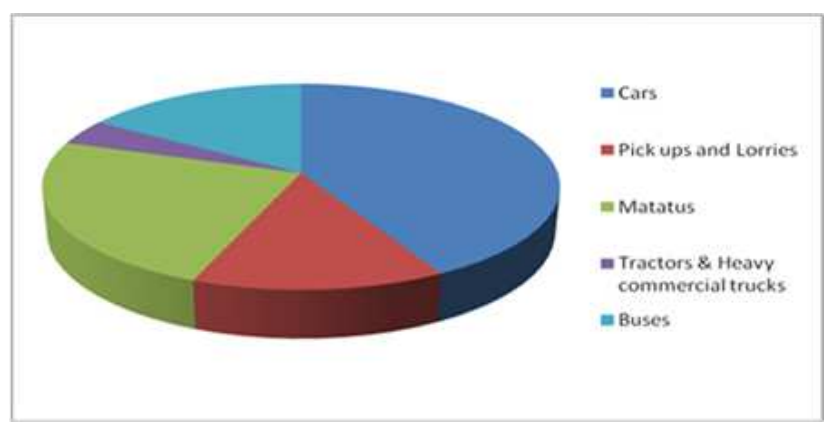

Figure 4. Unclaimed end of life vehicles by type. Source: Field work, 2013.

\subsection{Categories of Unclaimed End of Life Vehicles}

The study revealed that $100 \%$ respondents stated that there were vehicles that had been involved in accidents in the yards. The study established that traffic officers for other reasons had impounded the thirty $(\mathrm{n}=30)$ vehicles as illustrated in Fig.5. It was further established that one hundred and eighty four $(\mathrm{n}=184)$ vehicles had been involved in accidents as illustrated in Fig.6.

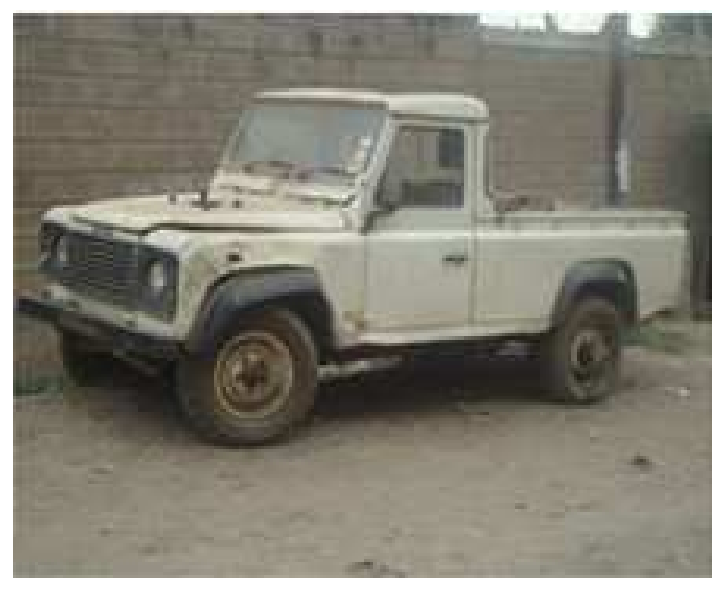

Figure 5. Natural end of life vehicle.

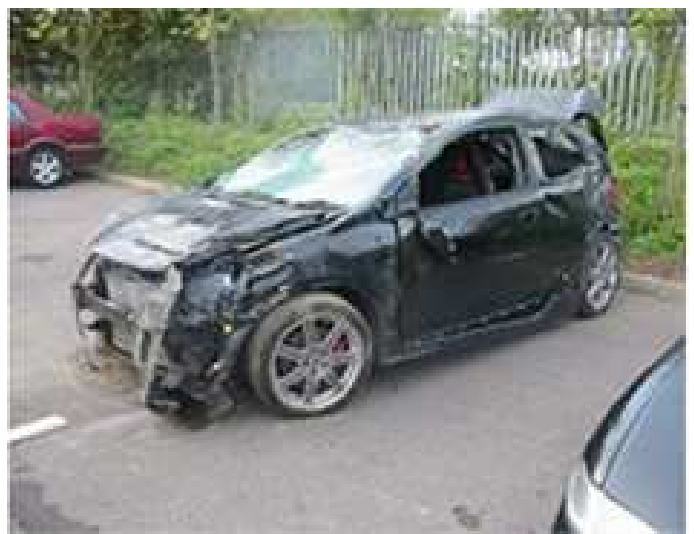

Figure 6. Premature end of life vehicle.

Premature (accident) vehicles commanded $86 \%$ of all vehicles, while $14 \%$ were due to natural causes. These findings clearly show that accidents contributed greatly to
ELV problem compared to on-road random inspection by traffic police officers.

\subsection{Environmental Impacts of Unclaimed End of Life Vehicles: Stakeholders' Views}

In order to identify different stakeholders' perceptions on end of life vehicles problem, 21 participants representing seven $(n=7)$ stakeholder groups were interviewed. Table 1 depicts an overview of the themes.

Table 1. Overview of themes.

\begin{tabular}{cl}
\hline Data display & \multicolumn{1}{c}{ Themes } \\
\hline 4.4.1. & $\begin{array}{l}\text { Theme 1: awareness of end of life vehicles as an } \\
\text { environmental issue and need for a policy }\end{array}$ \\
4.4.2. & $\begin{array}{l}\text { Theme 2: perception of unclaimed end of life } \\
\text { vehicles by vehicle type }\end{array}$ \\
& $\begin{array}{l}\text { Theme 3: potential environmental impacts and } \\
\text { possible interventions }\end{array}$ \\
\hline
\end{tabular}

Source: Field work, 2013

Several themes emerged from the analysis of data that related to the potential impacts of unclaimed end of life vehicles. The data was categorized into three levels of abstraction with themes as most abstract and the most real, representing informants' experiences and opinions. The result of the data was discussed according to the main themes that emerged from the study. Appropriate direct quotes were used to clarify the results.

\subsubsection{Theme 1. Awareness of Unclaimed End of Life Vehicles as an Environmental Issue and Need for a Policy}

The major theme that emerged from this data was that of unclaimed end of life vehicles as an environmental issue and need for a policy. From the in-depth interviews, it was learnt that majority of the stakeholders were aware of this problem of end of life vehicles. Data shown in Table 2 give informants' expressions on unclaimed end of life vehicles and need for a policy.

From Table 2, it was apparent that all respondents elaborated upon unclaimed end of life vehicles as an environmental issue except one. The dissenting opinion about end of life vehicles as an environmental issue was expressed:

"I do not see any environmental issue here in Kenya. This is a very new frontier in solid waste management. Let us deal the known first before we tackle the unknown. If we do not deal with issues like deforestation ....we extend blame on other sectors (MOA)."

Two stakeholders representing the view of absolute majority gave an example of unclaimed end of life vehicles as an environmental issue said: "The vehicles have become an eyesore and they present a major health hazard whether in police stations yards or elsewhere (MEMR, KIPPRA)." 
Table 2. Awareness of unclaimed end of life vehicles as an environmental issue including need for s policy (+ in support of, - against, +/- Ambivalent.

\begin{tabular}{cccc}
\hline Stakeholder & $\mathbf{n}$ & $\begin{array}{c}\text { Unclaimed ELVs as } \\
\text { an environmental } \\
\text { issue }\end{array}$ & $\begin{array}{c}\text { Need for an } \\
\text { ELVs policy }\end{array}$ \\
\hline $\begin{array}{c}\text { Matatu owners } \\
\text { association(MOA) }\end{array}$ & 7 & - & - \\
$\begin{array}{c}\text { Insurance } \\
\text { companies(IRA) }\end{array}$ & 3 & $+/-$ & + +- \\
$\begin{array}{c}\text { Automotive } \\
\text { repairers(KARA) }\end{array}$ & 3 & + & + \\
$\begin{array}{c}\text { Ministry of } \\
\text { transport (MOT) } \\
\text { Ministry of }\end{array}$ & 2 & + & + \\
environment \& \\
mineral resources \\
(MEMR)
\end{tabular}

Another respondent said: "Unclaimed end of life vehicles is a pile up of health hazards and a major blight on the environment '(MEMR)."

It is only one of the respondents' perceived end of life vehicles policy as positive and refers to it as follows:

"Unclaimed end of life vehicles must be included in the disposal of uncollected goods Act (CAP 38) to allow for easier disposal and recovery of costs involved (MOT)."

The respondents from matatu owners association (MOA) were negative:

"The policy will increase the possibility of extortion for bribery by the principal agents of the government. Let us leave it for now (MOA)."

Whereas the insurance companies were more ambivalent:

"We only claim vehicles after clearance by police department and court cases take much time (IRA)."

\subsubsection{Theme 2. Perception of Unclaimed End of Life Vehicles by Vehicle Type}

The second theme that emerged from the data was that of stakeholders' perceptions of unclaimed end of life vehicles by vehicle type. Data represented in Table 3 outlined the views on this theme.

Source: Field work, 2013

Table 3. Perceptions of unclaimed end of life vehicles by type.

\begin{tabular}{|c|c|c|c|c|c|c|}
\hline \multirow[b]{2}{*}{ Stakeholder } & \multirow[b]{2}{*}{$\mathbf{n}$} & \multicolumn{5}{|c|}{ Vehicle type } \\
\hline & & Matatus & Cars & Buses & P/ups \&lorries & $\begin{array}{c}\text { Heavy trucks \& } \\
\text { tractors }\end{array}$ \\
\hline Matatu owners association(MOA) & 7 & 2 & 3 & 1 & 1 & ---- \\
\hline Insurance companies(IRA) & 3 & 1 & 1 & 1 & --- & ---- \\
\hline Automotive repairers(KARA) & 3 & 1 & 2 & ---- & ---- & ---- \\
\hline Ministry of transport (MOT) & 2 & 1 & 1 & --- & & ---- \\
\hline $\begin{array}{l}\text { Ministry of environment \& } \\
\text { mineral resources (MEMR) }\end{array}$ & 2 & 1 & 1 & & & \\
\hline KIPPRA & 2 & 1 & 1 & --- & ---- & ---- \\
\hline Kenya vision 2030 secretariat & 2 & 1 & 1 & ---- & ---- & ---- \\
\hline Total & 21 & 8 & 10 & 2 & 1 & ---- \\
\hline
\end{tabular}

Source: Field work, 2013

From the interviews, $86 \%$ (18 of 21 ) respondents perceived that cars and matatus are the predominant types of vehicles unclaimed from police stations.

One respondent commented: "Matatus and cars are dominant on our roads and therefore we expect them to be more in our police stations ' yards (MOT).'

\subsubsection{Theme 3. Potential Environmental impacts and Possible Interventions}

Stakeholders described potential environmental impacts and possible interventions. From the data in Table 4, it is clear that health hazard risks, visual pollution and contamination of land and water supplies are the major environmental impacts identified. In addition to the potential impacts on the environment, possible interventions such as policy development were identified.

All stakeholders except one identified potential environmental impacts as follows: "End of life vehicles are a major health hazard and breeding grounds for disease causing organisms."

Another stakeholder identified contamination of land and water supplies by oil and other leaking fluids from the vehicles (KARA).Several of the respondents particularly those within various ministries identified the most important intervention as policy development. Another stakeholder expressed his view about intervention as follows: "We should deregister end of life vehicles and dispose to authorized treatment facilities for dismantling and recovery of saleable parts (IRA)."

\section{Discussion}

\subsection{Nature and Extent of Unclaimed End of Life Vehicles}

The study revealed that the police stations had unclaimed, non-operational vehicles in their yards. In total, there were two hundred and forty $(\mathrm{n}=240)$ unclaimed, non-operational 
vehicles in their yards. Out of these, $11 \%$ belonged to the police stations. On the issue of the different types of unclaimed, non-operational vehicles in the police yards, the study revealed that majority of the vehicles in the police yards were cars comprising $42 \%(n=90)$ while $24 \%(n=51)$ were matatus. 16 percent of the vehicles were buses while 14 percent were pickups and Lorries.

Table 4. Potential environment impacts and possible interventions.

\begin{tabular}{|c|c|c|c|}
\hline Stakeholder & $n$ & $\begin{array}{l}\text { Environmental } \\
\text { impacts }\end{array}$ & Interventions \\
\hline $\begin{array}{l}\text { Matatu owners } \\
\text { association(MOA) }\end{array}$ & 7 & Not sure & - \\
\hline $\begin{array}{l}\text { Insurance } \\
\text { companies(IRA) }\end{array}$ & 3 & $\begin{array}{l}\text { Health } \\
\text { hazards/Visual } \\
\text { pollution }\end{array}$ & $\begin{array}{l}\text { Deregistration of } \\
\text { ELVS and disposa } \\
\text { to ATFs }{ }^{l}\end{array}$ \\
\hline $\begin{array}{l}\text { Automotive } \\
\text { repairers(KARA) }\end{array}$ & 3 & $\begin{array}{l}\text { Health } \\
\text { hazards/Visual } \\
\text { pollution }\end{array}$ & Policy \\
\hline $\begin{array}{l}\text { Ministry of transport } \\
\text { (MOT) }\end{array}$ & 2 & Health hazards & Policy \\
\hline $\begin{array}{l}\text { Ministry of } \\
\text { environment and } \\
\text { mineral resources } \\
\text { (MEMR) }\end{array}$ & 2 & $\begin{array}{l}\text { Contamination of } \\
\text { land \& water } \\
\text { supplies }\end{array}$ & Policy \\
\hline KIPPRA & 2 & Health hazards & Policy \\
\hline $\begin{array}{l}\text { Kenya vision } 2030 \\
\text { secretariat }\end{array}$ & 2 & Health hazards & Policy \\
\hline Total & 21 & $\begin{array}{l}\text { Contamination of } \\
\text { land \& water } \\
\text { supplies }\end{array}$ & \\
\hline
\end{tabular}

Source: Field work, 2013

The study also revealed that 184 vehicles representing $86 \%$ were vehicles involved in road traffic accidents while the remaining $14 \%$ were in the yards due to other reasons.

The results of this study were clearly contrary to initial expectations. The null hypothesis suggested that there was no significant difference in the buildup of unclaimed end of life vehicles in police stations' yards by vehicle types. Exactly the reverse was observed -the buildup of unclaimed end of life vehicles showed significant difference by vehicle type $\left(\mathrm{H}=62.8, \chi^{2}=9.49(\mathrm{df}=4), \mathrm{p}=0.05\right)$.

A plausible explanation of the outcome is - the more the number of certain vehicle types on our roads, the higher the chances of these vehicles being involved in traffic offences and hence more of them finding their way to the police stations' yards.

Majority of the participants (18 out of 21) felt that cars and matatus were the predominant type of unclaimed end of life vehicles in the police stations' yards. Underlying this view was the impact of increase in vehicle ownership in Kenya and dangerous driving by matatu drivers.

\footnotetext{
1 Authorized treatment facilities
}

King'ori [3] observed that passenger car commanded 36\% of Nairobi vehicle counts, while pick-ups were $23 \%, 27 \%$ were matatus and $3 \%$ were buses. The study findings indicated unclaimed end of life vehicles as follows: $42 \%$ passenger cars, $24 \%$ matatus, $14 \%$ pick-ups, $16 \%$ buses and $4 \%$ heavy trucks/tractors. The report is also in agreement with Gachuki [10] who observed that matatus caused 19\% and passenger cars $25 \%$ of all accidents on Kenyan roads.

The buildup of unclaimed end of life vehicles in the different police stations was significantly dependent on location of the police station $\left(\chi_{\text {Calculated }}^{2}=48.42(\mathrm{df}=23)\right.$ and $\left.\chi_{\text {critical }}^{2}=35.17, \mathrm{p}=0.05\right)$. An explanation that seems more plausible - police stations located along highways or major roads handle more cases than other police stations located elsewhere.

The study found out a positive correlation between unclaimed premature (accident) end of life vehicles and natural end of life vehicles $(\mathrm{r}=0.389)$. The correlation is not significant at $\mathrm{p}=0.05$. The outcome could be for the reason that accidents are not pre-planned, but on-road random inspections were planned. The study revealed that the inspections were less often carried out.

\subsection{Environmental Impacts Associated with Unclaimed End of Life Vehicles}

The study findings agree with Cassells [11] environmental concerns regarding dumped vehicles. The study findings established potential environmental impacts; first, contamination of land and water supplies is likely impact by end of life vehicles. These vehicles are kept in open areas and hence there is the likelihood of leakage of fluids into soil and water. If oil finds its way into sewers and water courses it can cause significant contamination-

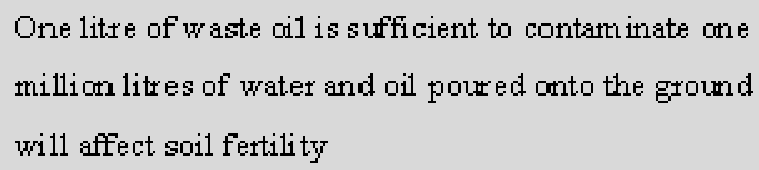

Secondly, these vehicles pose a health hazard to children living within the police stations. Most police stations have residential houses for officers but have no designated playing grounds for children. Lastly, the study revealed that unclaimed end of life vehicles are likely breeding places for rodents and pathogens besides causing obstruction (visual pollution) within the police station.

Most stakeholders had good awareness of end of life vehicles as an environmental issue and the need for a policy. There was actually higher awareness of the potential health consequences as a result of the stockpiles of end of life vehicles. In particular, all the respondents except one were clear about waste associated with vehicles such as engine and hydraulic oil, batteries, heavy metals, air conditioning gases and radiator fluid. Two stakeholders mentioned contamination of land and water supplies by the end of life vehicles waste. 


\section{Conclusion}

The results of this study provide some fascinating insights on unclaimed end of life vehicles in police stations' yards. In total, there were two hundred and forty unclaimed, non-operational vehicles in their yards. Out of these, only 26 belonged to the police stations. Cars were the predominant type while heavy trucks/tractors were the least common in the yards. The study shows that the unclaimed, non-operational vehicles had cost of externality as a result of environmental pollution. After a lengthy stay in the yards, the end of life vehicles suffer impairment loss (amount by which the carrying amount of an asset exceeds the recoverable amount).

The study further proves that potential environmental impacts by the accumulation of end of life vehicles were leakages of fluids such as engine oil, transmission fluids, and battery fluids on the yard since $86 \%$ of the respondents stated that most of these vehicles are stored in open areas. Other impacts are health hazard risks to children living within police stations, possible injuries due to rusting, broken vehicle parts, obstruction (visual pollution) and breeding grounds for mosquitoes and other pathogens.

At the time of the study, there was no specific regulation for management and disposal of end of life vehicles in Kenya. In view of the research findings and results the following recommendations were put forward:

- End of life vehicles policy development as a guide in ELV waste management in Kenya.

- Since it is apparent that there is pile up of end of life vehicles, the study recommends that there is need for proper storage and disposal of unclaimed end of life vehicles in police stations' yards. This can be done through storage in yards away from police station and proper checking of leakages before storage of the end of life vehicles.

- There is need for legislation that will ensure that ELVs are handled, stored and disposed in a more environmentally responsible manner.

- Since passenger cars and matatus are the predominant types of unclaimed ELVs, there is need for awareness creation on the benefits and importance of comprehensive insurance cover to third party insurance cover for these types of vehicles. This will help insurance in taking up ownership in case of accidents. Comprehensive cover is deemed expensive and matatus prefer third party insurance. The insurance industry should come up with standardized full motor insurance through the insurance Act.

- The study revealed that majority of the ELVs are kept in open areas, there is need for the government to engage the services of storage providers or minimize environmental pollution impacts by storing the vehicles indoors or in areas with impervious floors.

- With the need to manage environmental pollution by ELVs even after disposal, the government should only deal with authorized treatment facilities to ensure environmental performances of ELV treatment systems are sound.

- Further research is needed to assess the environmental performances of garages or treatment facilities that deal with end of life vehicles in Kenya.

- More research is necessary to explore the role of scrap metal dealers in environmental management in Kenya.

\section{Acknowledgements}

I am indebted to members of staff in the department of geography and environmental studies, university of Nairobi. Likewise, am especially grateful to Dr. Omoke, Dr. Nyongesa, Dr. Farida Were and Mr. Haggai Namai for their guidance in the research work. This study would not have been possible without cooperation from police stations and other organizations in Nairobi. I am obliged to the higher education loans board (HELB) for financial support.

\section{References}

[1] Kanari, N., Pineau, L., \& Shellari S. (2003). End of life vehicles recycling in Europe. Journal of the minerals, metals and materials society. 8(10):15-19.

[2] Zoboli, R., Barbiroli.G. Leonicini R., Mazzirati, M., \& Montresor, S. (2000). Regulation and innovation in the area of end of life vehicles, EUR19598EN. (Ed.)F.Leone (Italy: IDSE-CNR).

[3] King'ori, Z.I (2007). Nairobi urban transportation challenges-learning from Japan. JICA training course. Retrieved March 16,2013,from

http://www.scribd.com/doc/2369220/FINAL-REPORT-NAI ROBI -CITY.

[4] European Union. (2000).Directive 2000/53/EC of the European Parliament and of the Council of 18 September 2000 on end-of life vehicles. Journal of the European Communities.

[5] Tipping, A. (1998). What happens to a car when it reaches the end of its useful life?

[6] Cassells, S. (2001). Deficiencies in New Zealand's approach to recycling end of life vehicles. Discussion paper. No 01.05., Department of applied and international economics, Massey University, New Zealand

[7] Arbitman, N., \& Gerel, M. (2003). Managing end of life vehicles to minimize environmental harm, white paper on sustainable conservation's auto-recycling project. Retrieved March 16, 2013, from http://www.suscon.org.

[8] Sakai, S., Noma, Y. \& Kida A. (2007). End of life vehicle recycling and automobile shredder residue management in Japan. Journal of Material Cycles and Waste Management 9 (2):151-158.

[9] Chen. (2005). End of life vehicle recycling in China: Now and the future. Retrieved March 16, 2013, from http:// www.resources.metapress.com.

[10] Gachuki, D. (2004). A brief commentary on legal notice No. 161. IPAR. Kenya: Regal press. 

Police Stations' Yards: A Case Study of Nairobi, Kenya

[11] Cassells, S., Holland, J., \& Meister, A. (2005). End-of -life vehicle disposal: policy proposals to resolve an environmental issue in New Zealand. Journal of Environmental Policy \& Planning. 7(2):107-124. 